\title{
An enzyme net coating the surface of nanoparticles: a simple and efficient method for the immobilization of phospholipase D
}

Binglin Li $i^{\ddagger}$ Jiao Wang ${ }^{\ddagger}$ Xiaoli Zhang*, Binxia Zhao

Dept. of Chemical Engineering, University of Northwest University, 229 North Taibai Road, Xi'an, 710069, Shaanxi, China.

These authors contributed equally to this work.

*Corresponding author

Xiaoli Zhang

Dept. of Chemical Engineering, Northwest University

ADD: 229 North Taibai Road,Xi'an, 710069, Shaanxi Province,China

TEL: ++86-29-84198933

FAX: $++86-29-84198933$

Email: xlzhang@nwu.edu.cn 


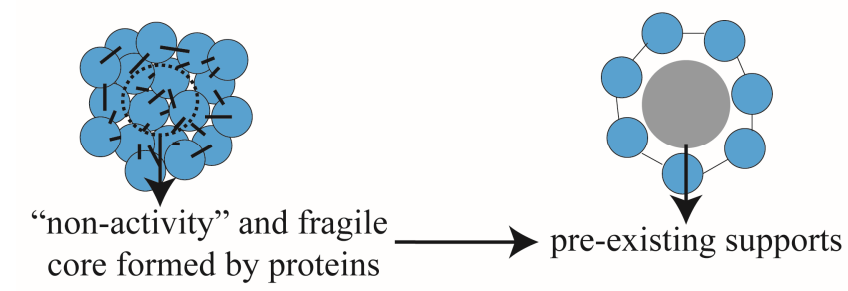

Figure S1: Schematic overview of the use of pre-existing non-porous solids (gray) instead of the "non-activity" and fragile core (blue) of aggregations of enzymes.

(in the organic phase)

(in the aqueous phase)

(in the organic phase)
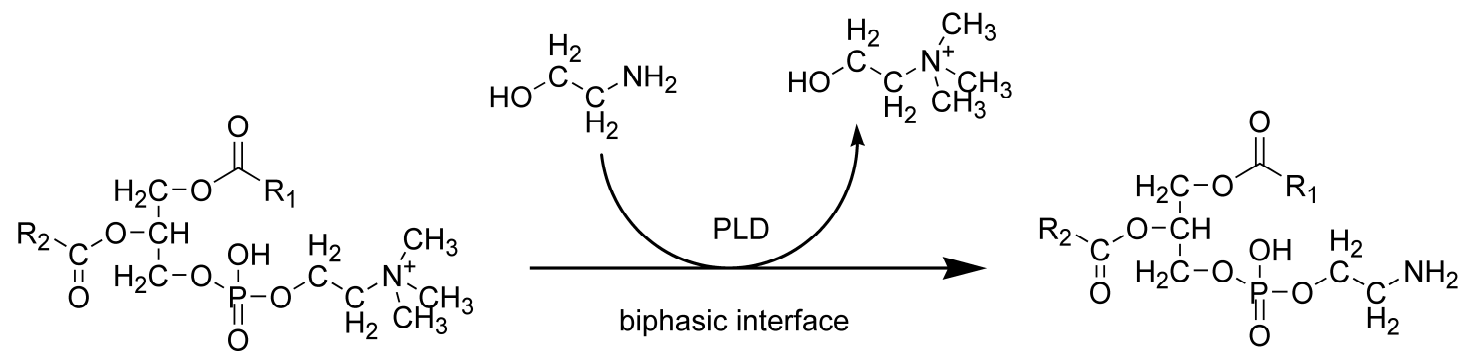

Figure S2: Schematic overview of the reaction equation of transphosphatidylation.

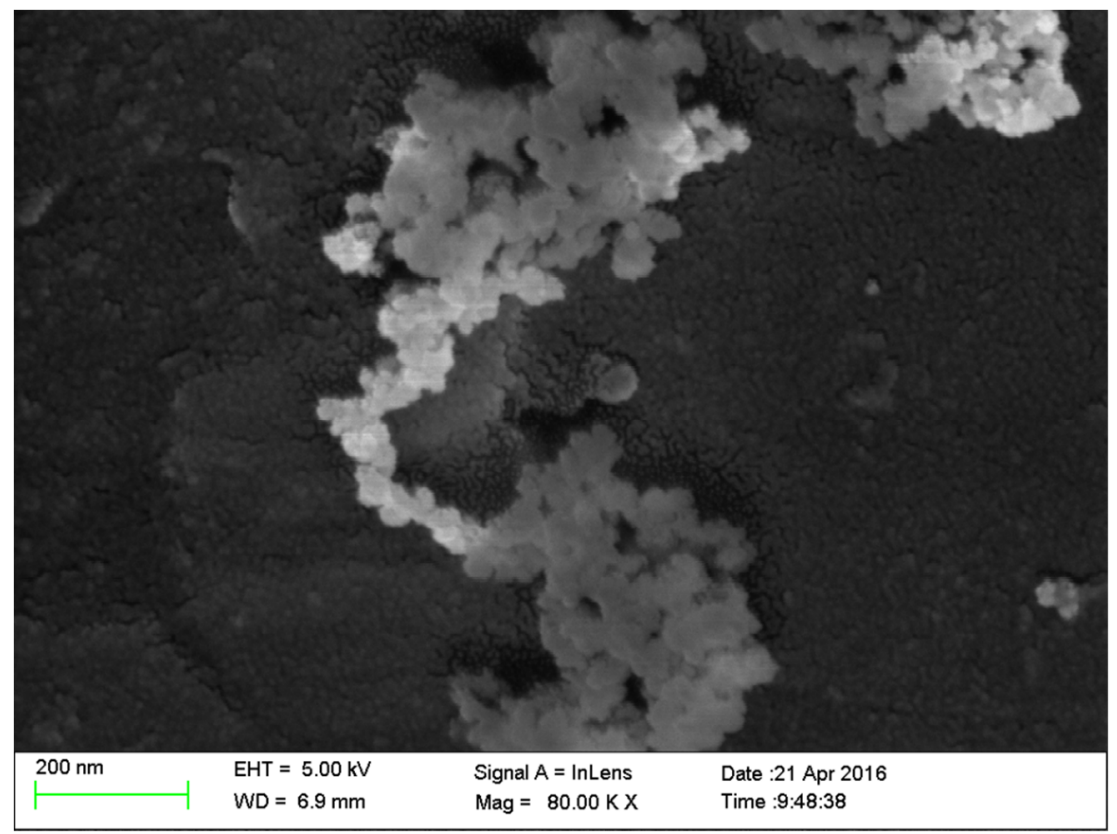

Figure S3: SEM micrographs of nanoscale silicon dioxide without immobilized enzymes. 
The effect of rotational speeds on transphosphatidylation for free and immobilized PLD

To obtain the optimum PLD-catalyzed transphosphatidylation conditions, the reaction was carried out in biphasic systems. Free or immobilized PLD solution $(0.1 \mathrm{~mL}$, $\left.3.30 \times 10^{-4} \mathrm{~g}_{\text {protein }} / \mathrm{mL}\right)$ was added into $0.7 \mathrm{~mL}$ acetate buffer $(0.2 \mathrm{M}, \mathrm{pH} 5.5$ for free PLD or 6.0 for immobilized PLD). The concentration of ethanolamine in the above mixture is $50 \mathrm{mM}$. The reaction was then initiated by adding $1.6 \mathrm{~mL}$ diethyl ether containing 10 $\mathrm{mM}$ PC, and incubated at 100-300 rpm and 30 (free PLD) or 35 (immobilized PLD) ${ }^{\circ} \mathrm{C}$.

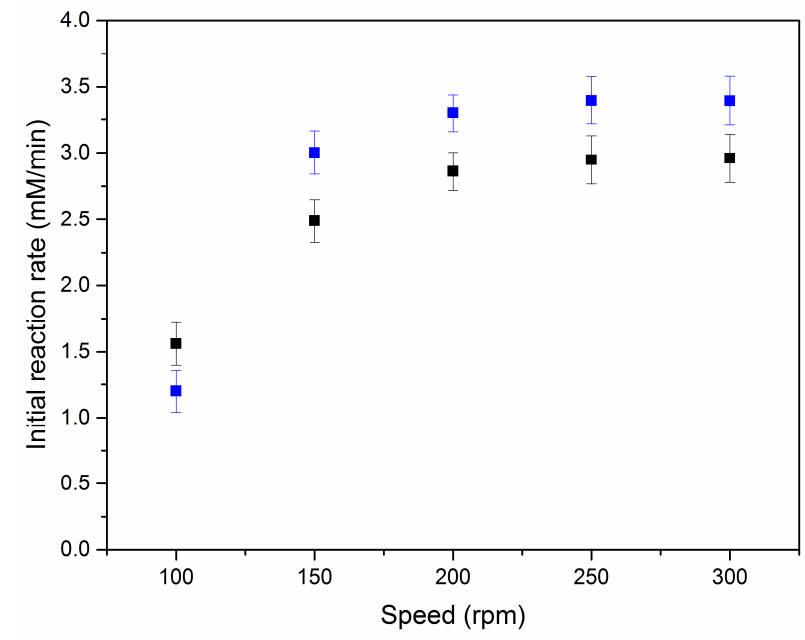

Figure S4: The effect of rotational speeds on transphosphatidylation for free (black) and immobilized (blue) PLD. 


\section{The effect of the concentration of ethanol amine on the reaction rate of}

\section{transphosphatidylation for free and immobilized PLD}

To simplify the kinetic model, the reaction was carried out in biphasic systems. Free or immobilized PLD solution $\left(0.1 \mathrm{~mL}, 3.30 \times 10^{-4}\right.$ g protein $\left./ \mathrm{mL}\right)$ was added into $0.7 \mathrm{~mL}$ acetate buffer $(0.2 \mathrm{M}$, pH 5.5 for free PLD or 6.0 for immobilized PLD). The concentration of ethanolamine in the above mixture ranged from $0-250 \mathrm{mM}$. The reaction was then initiated by adding $1.6 \mathrm{~mL}$ diethyl ether containing $10 \mathrm{mM} \mathrm{PC}$, and incubated at $200 \mathrm{rpm}$ and 30 (free PLD) or 35 (immobilized PLD) ${ }^{\circ} \mathrm{C}$.

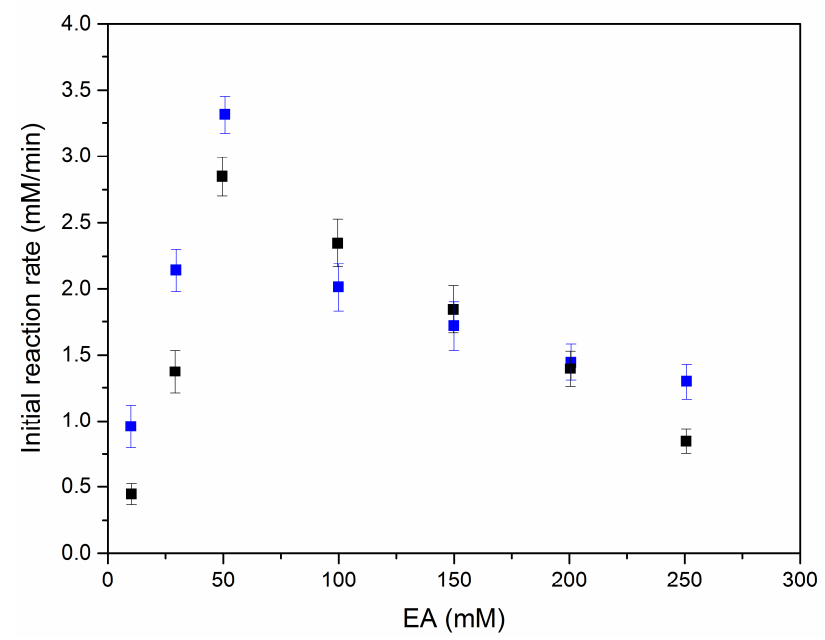

Figure S5: The effect of the concentration of ethanol amine on the reaction rate of transphosphatidylation for free (black) and immobilized (blue) PLD. 